\title{
Introduction to the Research Handbook on EU Environmental Law: The Challenge of Understanding EU Environmental Law Marjan Peeters and Mariolina Eliantonio
}

\section{TAKING STOCK OF EU ENVIRONMENTAL LAW AND PROSPECTS ON ITS FURTHER DEVELOPMENT}

This book aims to draw insights into the use of different regulatory instruments by the EU and the role of the CJEU in putting them into practice in the field of EU environmental law. Since the First Environmental Action Plan from 1973, ${ }^{1}$ the $A D B H U$ case from 1985, in which the European Court of Justice confirmed that environmental protection is 'one of the Community's essential objectives', ${ }^{2}$ and the Single European Act from 1987, which introduced an explicit basis for environmental legislation, and for which the Maastricht Treaty from 1991 introduced qualified majority voting in the Council, ${ }^{3}$ a vast body of EU environmental legislation has come into existence. ${ }^{4}$ It is however an arduous task to acquire adequate insight into the main characteristics and structure of the whole body of EU environmental legislation, let alone comprehensive knowledge of the vast amount of individual provisions of the environmental acquis, including the relevant case law.

While students of EU environmental law perhaps expect teachers to provide a systematic explanation of the numerous directives, regulations and decisions in the field of EU environmental law, the disappointing message to them is that no clear structure exists and that the development of EU environmental rules happened in a rather fragmented way, making the whole body difficult to comprehend and systematise. Even more challenging

1 Declaration of the Council of the European Communities and of the representatives of the Governments of the Member States meeting in the Council of 22 November 1973 on the programme of action of the European Communities on the environment, OJ $1973 \mathrm{C} 112 / 1$, which states in its preamble: 'Whereas improvement in the quality of life and the protection of the natural environment are among the fundamental tasks of the Community; whereas it is therefore necessary to implement a Community environment policy.'

2 C-240/83, Procureur de la République v ADBHU, para 13, ECLI:EU:C:1985:59.

3 The Amsterdam Treaty (1997) improved the position of the European Parliament by introducing the co-decision procedure also for environmental decision-making.

4 See, among other handbooks explaining the history and development of EU environmental law: Jan H. Jans and Hans H.B. Vedder, European Environmental Law. After Lisbon (Europa Law Publishing 2012), chapter 1, and Jane Holder and Maria Lee, Environmental Protection, Law and Policy, (Cambridge University Press 2007), chapter 4. As Helle Tegner Anker observes in her chapter, since the early 70s EU environmental legislation has grown steadily and today covers a variety of different measures and instruments. Some environmental measures have already had a long lifespan. The Waste Framework Directive (WFD), being adopted in 1975, is one of the oldest pieces of EU environmental law; see on the WFD and its evolution the chapter by Chris Backes. 


\section{Research Handbook on EU Environmental Law}

is the effort to get intelligible insight into the application of EU environmental law, so as to be able to measure compliance, and to assess whether such compliance leads to the desired effects. One of the most fundamental issues of environmental law in general is how to achieve an adequate level of protection, also in view of the difficult weighing of environmental, economic and social interests, including the impact on lifestyles when considering new obligations steering to less polluting behaviour.

Related to this point, fundamental values as enshrined in EU primary law are important to hold decision-makers to account, such as the rule laid down in the very first Article of the Treaty on European Union, stating that 'decisions are taken as openly as possible and as closely as possible to the citizen'. The Aarhus Convention from 1998 has re-enforced the already existing approach in EU law that the public needs to get wide access to environmental information, but has also confronted the EU with the challenge to act in compliance with the obligation to provide adequate access to administrative or judicial procedures for ENGOs, citizens and other actors in order to address non-compliance with environmental legislation by private and public actors. ${ }^{5}$ Next to this, public participation procedures need to be provided in order to debate the specific protection to be given to the environment in decisions, plans, programmes and (executive) regulations. ${ }^{6}$

Given the worrisome state of affairs of parts of the environment, even after more than four decades of environmental decision-making, a debate aimed at strengthening the ambition of environmental law, particularly climate law, is at the forefront of politics, as can be noticed in the pledges the candidate for the position of chair for the European Commission made in her statement before the European Parliament on 16 July 2019: 'Our most pressing challenge is keeping our planet healthy. This is the greatest responsibility and opportunity of our times.' 7

\section{STRUCTURE AND APPROACH TO EXAMINE THE INSCRUTABLE FIELD OF EU ENVIRONMENTAL LAW}

By bringing together countries geographically spread over respectively eight EU member states, one country being a party to the European Economic Area (Norway), and one country outside the European continent (Nigeria), this book aims to provide a rich and thorough discussion of the state of affairs of EU environmental law, thereby not only pointing at success, but also at outstanding challenges and opportunities for improving its content and application. Some chapters move to some extent beyond traditional legal scholarship, using insights from, for example, political science, economics

5 Article 9(3) of the UNECE Convention on Access to Information, Public Participation in Decision-making and Access to Justice in Environmental Matters (Aarhus Convention).

6 Part II of this book will discuss the implementation of the three pillars of the Aarhus Convention into EU law.

7 Ursula von der Leyen, Candidate for President of the European Commission Opening Statement in the European Parliament Plenary Session, Strasbourg 16 July 2019, available at https://ec.europa.eu/commission/sites/beta-political/files/opening-statement-plenary-session_en_2. pdf (last accessed 12 February 2020). 
and psychology to discuss the shortcomings of the legal framework and possible ways for addressing them. ${ }^{8}$

The first part of the book (Part I: Institutional and Horizontal Issues) illustrates that EU environmental law cannot be understood without a thorough knowledge of EU institutional law. The development and application of EU environmental law is dependent on the proper use of EU competences, its compatibility with the Treaties and the general principles of EU law, including the Charter of Fundamental Rights of the European Union, and, specifically, the rules on the free movement of goods. While not all such general EU law aspects can be discussed in this Part, seven selected chapters introduce the reader to respectively the breadth and width of EU environmental competences (Helle Tegner Anker), the guiding relevance of environmental principles, including the objective of sustainable development (Gyula Bándi), the possibility for Member States to adopt more stringent measures - which have to be in conformity with the Treaties and the general principles of EU law (Leonie Reins), the agencification process in the field of EU environmental law (Annalisa Volpato and Ellen Vos), the external dimension of EU environmental law in view of the main developments brought about by the Lisbon Treaty (Antonio Cardesa-Salzmann and Elisa Morgera), the impact of the rules on the free movement of goods - and particularly the related case law - on the possibility to adopt national environmental protection measures (Geert van Calster) and the phenomenon of transnational acts in the field of EU environmental law (Luca De Lucia and Maria Chiara Romano).

Part II continues with the theme of procedural rights in the field of EU environmental law, including access to environmental information (Uzuazo Etemire), public participation to governmental decision-making (Lorenzo Squintani and Goda Perlaviciute), access to justice in environmental matters (Matthijs van Wolferen and Mariolina Eliantonio) and environmental impact assessment procedures (Agustín García-Ureta).

Presumably the weakest part of EU environmental law - and perhaps this applies to environmental law across the globe - is the low compliance with the adopted provisions. In the EU context, this non-compliance is not only caused by private actors, but also by (authorities of) Member States who fail to implement binding EU environmental measures correctly. Part III provides three chapters on specific compliance mechanisms. First of all, attention goes to the concept of direct effect in EU environmental law, which enables citizens and ENGOs to address non-compliance with EU environmental law but, importantly, also to the emerging force of the doctrine of consistent interpretation (Ludwig Krämer); secondly, the necessity to strengthen the EU law approach to environmental inspection by public authorities is discussed (Martin Hedemann-Robinson) and, thirdly, the enforcement of the EU environmental law acquis by Member States through infringement actions initiated by the European Commission is analysed (Melanie Smith).

If environmental damage occurs, liability issues emerge, which include both liability with respect to restoring the damage, and criminal liability. Moreover, only strong liability approaches may contribute to preventing damage from happening. Two liability

8 See the chapters from Nathalie Hervé-Fournereau, Andrew Johnston and Beate Sjåfjell, Giulia Claudia Leonelli, Lorenzo Squintani and Goda Perlaviciute, Estelle Brosset and Sandrine Maljean-Dubois, Stefan Weishaar, and Thomas Schomerus. 
approaches are discussed in Part IV, with a chapter on the Environmental Liability Directive (Barbara Pozzo) and a chapter on criminal environmental liability (Michael Faure), and both chapters show the limits of the approaches codified in the relevant EU directives.

Part $\mathrm{V}$ delves into the fragmented substance of EU environmental law. It is truly not easy to discuss the often very complex and technical content of substantive environmental law, and we are very glad to present nine chapters that managed to identify the main developments and challenges in the field of EU nature conservation law (An Cliquet), the Water Framework Directive (Nathalie Hervé-Fournerau), EU air pollution law (Kendro Pedrosa and Bernard Vanheusden), integrated pollution and prevention control (Lolke Braaksma and Hanna Tolsma), the Waste Framework Directive and the circular economy (Chris Backes), the regulation of Industrial Chemicals (Reach) (Martin Führ \& Julian Schenten), the regulation of genetically modified organisms (Giulia Claudia Leonelli), car emissions standards, including its relates scandal (Nicolas de Sadeleer) and, finally, the (lack of) EU legislation to promote environmental sustainable corporate behaviour (Beate Sjåfjell and Andrew Johnston).

Part VI continues with the substantive focus, providing special attention to EU regulatory action addressing the emerging climate change problem. The four chapters of this part concentrate on several important pillars of the EU climate law acquis. First, the development of EU climate law in view of the Paris Agreement and in particular the new governance approach introduced in 2018 specifically for EU energy and climate action is discussed (Estelle Brosset and Sandrine Maljean-Dubois). More specific regulatory approaches are presented in the chapters on the individual greenhouse gas emission reduction targets for Member States, including the regulation on absorption and release of carbon dioxide related to Land Use, Land Use Change and Forestry (Seita Romppanen), EU emissions trading (Stefan Weishaar), and, last but not least, the energy-efficiency approach, which is set as the first priority within EU climate and energy law (Thomas Schomerus).

When inviting the contributors for the chapters mentioned above, we have asked them to try to concentrate on two main research objectives, namely: (1) to identify the regulatory approach and the main regulatory developments in a specific field of EU environmental law (this research question is mainly relevant for the substantive Parts V and VI); and (2) to identify the way in which the CJEU has tried to reach its decisions (notably: legalistic or activistic?). ${ }^{9}$ At the same time, while reviewing all chapters intensively content-wise, we provided also quite some liberty to the direction the authors wanted to take themselves in

9 However, given the dynamic development of EU environmental legislation some chapters focus on the content of (newly) adopted legislation for which no important case law has yet emerged, such as is the case with the Governance of the Energy Union and Climate Action Regulation, the Effort Sharing Regulation and the LULUCF Regulation, and the amended Energy Efficiency Directive. Furthermore, while most of the topics can be characterised by a large amount of court decisions, as is for example evidently the case concerning access to environmental information law, environmental impact assessment law, nature conservation law, waste law, air quality law and the EU emissions trading scheme, other topics have seen much fewer decisions from the CJEU, such as is the case with the industrial emissions law, the Environmental Liability Directive and the Directive on Criminal Environmental Liability. 
their chapters, in order to achieve a rich collection of scholarly views on what the authors think are the most important issues (and court rulings) to discuss when examining the state of the art of EU environmental law. The concluding chapter in Part VII of this book will provide overall insights that we think can be derived from this collection of chapters.

\section{OUTLOOK AND ACKNOWLEDGMENTS}

We hope that this book contributes to the best understanding possible of EU environmental law, since we as scholars have an important task in informing students and society at large about the state of affairs of EU environmental law. ${ }^{10} \mathrm{We}$ sincerely thank all contributors for their effort to develop their chapters (and for being patient during the editorial process!). We are also very grateful to Javier Canales Luna and Monique Lundh, master students of the Law Faculty at Maastricht University in the academic year 2018-2019 and student research fellows to the METRO institute of this Law Faculty, for their editing support to some chapters. Finally, we would like to express our gratitude to Edward Elgar, and especially Ben Booth and his colleagues, for providing us with the opportunity to bring this book into existence.

10 See in this respect the concern expressed by Jacobs already in 2006 of the 'constant misrepresentation of the EU in some of the English media': Francis Jacobs, 'The Role of the European Court of Justice in the Protection of the Environment' (2006) 18 Journal of Environmental Law 205. 